\title{
Fruiting phenology and avian frugivory of Streblus asper Lour. In a mixed dry deciduous forest, Western Ghats, India
}

\author{
R. Aruna ${ }^{1,2, *}$, P. Balasubramanian ${ }^{1}$ \\ ${ }^{1}$ Division of Landscape Ecology, Salim Ali Centre for Ornithology and Natural History, \\ Coimbatore - 641 108, India \\ ${ }^{2}$ Department of Pharmacognosy, Siddha Central Research Institute, \\ Arumbakkam, Chennai - 600 106, India \\ *E-mail address: arsbot@gmail.com
}

\begin{abstract}
This paper describes the fruiting phenology and avian frugivory of Streblus asper (Moraceae) in a mixed dry deciduous forest, Anaikatty hills, Western Ghats. Fruiting occurred during April-June. Nine species of birds were found to feed on the ripe fruits of this species. Bulbuls (3 species) belonging to Pycnonotidae, followed by two species of Myna (Sturnidae) made majority of the feeding visits and appear to be the major seed dispersers of this species.
\end{abstract}

Keywords: Streblus asper; avian frugivory; phenology; mixed dry deciduous forest

\section{INTRODUCTION}

The phenology of tropical species has received much attention in the last three decades (Morellato, 2003; Medeiros et al. 2007); the general phenological aspects of leafing, flowering and fruiting in tropical tree species are fairly known (Frankie et al. 1974; Sun et al. 1996). Tropical plants with their high level of species diversity display phenological events such as leaf shedding, leaf flushing, flowering and fruiting in relation to time and space (Justiniano and Fredericksen, 2000; Singh and Singh, 1992).

Vertebrates depend on plants and are benefited by feeding nectar and fruits and the plant species are benefited by its pollinators and seed dispersers which aid in pollination and seed dispersal. Seed dispersal is one of the key processes determining the spatial structure of the plant population.

The study of relationships between bird-dispersed plants and fruit-eating birds in the tropical region has received considerable attention (Ali, 1931; Beehler, 1983; Balasubramanian, 1996; Aruna et al., 2009). Vertebrate animals are important dispersal agents and among them birds are perhaps most commonly associated with seed dispersal (Van der Pij1 1972).

Frugivory is the last step of the pre-dispersal reproductive phase and because these species interactions determine the location and environmental conditions in which seeds are 
deposited, they can also influence plant germination, survival, and forest regeneration (Chazdon 2003).

Streblus asper Lour. (Moraceae) is a small tree, up to $12 \mathrm{~m}$ high distributed in the drier parts of India, from Rohilkund, eastward and southwards to Travancore, Penang and the Andaman Islands (Hooker 1886). Moraceae forms an important family for wildlife as the Ficus spp sustain the frugivores almost throughout the year. However, the role of $S$. asper in supporting bird life in the forest is not known.

Hence, the present study aims to document the fruiting schedule of Streblus asper and its role in sustaining avian frugivores in a tropical mixed dry deciduous forest in Western Ghats.

\section{STUDY AREA}

The present study was carried out during in the mixed dry deciduous forests of Anaikatty hills in Coimbatore Forest Division, Western Ghats. It is situated at an elevation of about 610-750 m above MSL. The Anaikatty forest is located between Attapady and North east of Coimbatore. It is about $25 \mathrm{~km}$ from Coimbatore. This is an undulating terrain comprising the foothills and hills, situated between 760 39' and $76047^{\prime} \mathrm{E}$ and from 110 5' to $11031^{\prime} \mathrm{N}$ in Coimbatore Tamil Nadu, Southern India.

This area consisted of the combination of trees such as Acacia leucophloea, A. ferruginae, Ziziphus mauritiana, Chloroxylon swietenia, Albizia amara, Tamarindus indicus, Albizia lebbeck, Acacia polyacantha, Diospyros ferrea, Cassia fistula, Commiphora caudate. Domonant shrubs available in this forest are Chromolaena odorata, Clausena indica, Elaeodendron glacum, Flacourtia indica, Lantana camara, Lantana wightiana, Randia dumetorum, Premna tomentosa, pavetta indica and Mundulea sericea. Succulents such as Opuntia dillenii and Euphorbia antiquorum are also common. Anthropogenic pressure is exerted on the vegetation of these habitats.

This forest is rich in biodiversity. The mammalian fauna found here include Elephant (Elephas maximus), Gaur/Indian Bison (Bos gaurus), Sambar (Cervus unicolor), Chital (Axis axis), Leopard (Panthera pardus), Wild dog (Cuon alpinus), Sloth Bear (Melurus ursinus), Wild Boar (Sus scrofa), Common Langur (Presbytis/Semnopithecus entellus), Common Mangoose (Herpestes edwardsii) and Indian Three- striped Palm Squirrel (Funambulus palmarum).

\section{METHODOLOGY}

\section{1. Phenology}

Five individuals of Streblus asper were tagged and observed for phenology. The phenology of fruit production was observed twice in a month to assess the periodicity of fruiting as described in Frankie et al. (1974).

During the observation, percentage of ripe fruits in the canopy were visually estimated and noted for each individual. Phenological observations were carried out for 12 months from October 2006. 


\section{2. Bird foraging observations}

Foraging observations were made by extended bird feeding watches on fruit-bearing plants. Observations were made between 6.00 to $9.00 \mathrm{hrs}$ and 15.00 to $17.00 \mathrm{hrs}$ on bird visitation to fruit-yielding plants, with the help of binoculars. The visit made by each individual followed by pecking/swallowing of fruits was considered as a fruit-feeding visit by a bird. Number of visits made by different bird species was noted. Certain birds, particularly carnivores and insectivores simply perching on trees were not included in this observation as they are not frugivores. Three individuals of Streblus asper were observed for 12 hours each. Thus, a total of 36 hours of observations were made to record frugivores visits.

\section{RESULTS}

\section{1. Fruiting phenology}

Streblus asper bore fruits during summer (April-June). The fruiting peak was seen in May with all the tagged individuals in fruiting.

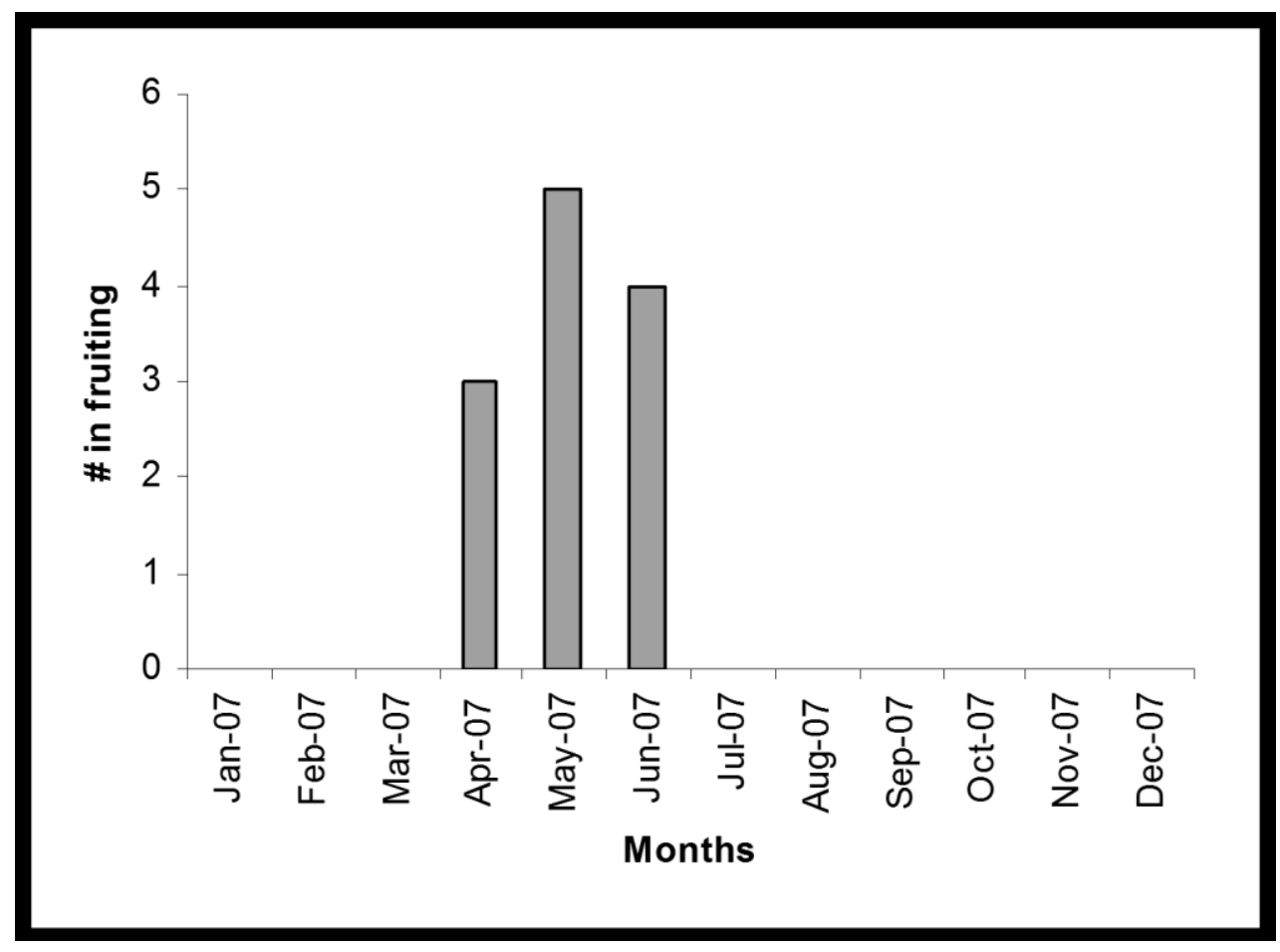

Figure 1. Fruiting phenology of Streblus asper in Anaikatty hills.

\section{2. Avian frugivory}

Nine species of birds (Acridotheres tristis, Chloropsis aurifrons, Eudynamys scolopacea, Phaenicophaeus viridirostris Pycnonotus cafer, Pycnonotus jocosus, Pycnonotus luteolus, Sturnus pagodarum and Turdoides affinis) were found to feed on the ripe fruits of Streblus asper. A total of 151 bird visits were recorded in which a majority was made by bulbuls ( 3 species), followed by Myna ( 2 species) followed by White-headed Babbler, Asian Koel, Gold-fronted Chloropsis and Small Green-billed Malkoha. 
Table 1. Proportion of foraging visits by different frugivorous birds on Streblus asper in Anaikatty hills.

\begin{tabular}{|c|c|c|c|}
\hline S. No & Common Name & \# of visits & \% of visits \\
\hline 1 & White-browed Bulbul & 32 & 21 \\
2 & Common Myna & 28 & 19 \\
3 & White-headed Babbler & 24 & 16 \\
4 & Red-whiskered Bulbul & 19 & 13 \\
5 & Red-vented Bulbul & 18 & 12 \\
6 & Brahminy Myna & 15 & 9 \\
7 & Asian Koel & 8 & 5 \\
8 & Gold-fronted Chloropsis & 4 & 3 \\
9 & Small Green-billed Malkoha & 3 & 2 \\
\hline
\end{tabular}

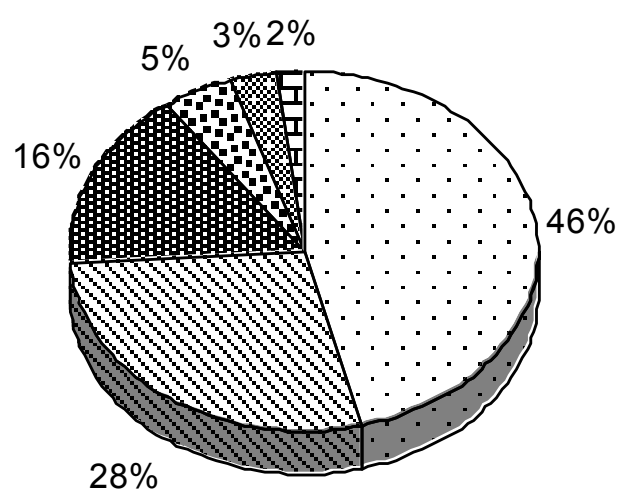

$\square$ Bulbul (3 species)

๑ Myna (2 species)

White-headed Babbler

四 Asian Koel

은 Gold-fronted

Chloropsis

田 Small green-billed

Malkoha

Figure 2. Avian frugivores of Streblus asper in Anaikatty. 


\section{DISCUSSION}

Bulbuls constituted the major frugivores of Streblus asper fruits in the mixed dry deciduous forests. Fruits comprised a major proportion of diet for bulbul species (Pycnonotus luteolus and P. cafer) in the tropical dry evergreen forest, Point Calimere (Vijayan, 1975). In Point Calimere, $74 \%$ of the feeding visits by birds on fruit bearing plants were made by two species of bulbuls, P. cafér and P. luteolus (Balasubramanian, 1996). In a dry mixed deciduous forest in Western Ghats, bulbuls formed the predominant frugivorous and seed dispersing species; the largest numbers of visits $(47.5 \%)$ were made by three species of bulbuls (Balasubramanian et al 1998).

Even though Ficus and Streblus belong to the same family (Moraceae), Streblus asper did not attract a wide variety of fruit eaters as that of the Ficus spp. The importance of figs as a key resource for frugivores in tropical forests has been emphasized in many studies (Kinnaird et al., 1996; Kannan and James, 1999). Lambert and Marshall (1991) pointed out that the combination of attributes such as large crop size, relative numerical abundance and aseasonal fruiting and availability even in periods of general fruit scarcity makes Ficus a unique and extremely important resource to frugivores. In the case of $S$. asper, its fruiting is highly seasonal and thus available for a short period only. Hence it could attract only a few avian frugivores of the study area. Also, figs are energy-rich foods and have higher caloric values than other fruits.

\section{CONCLUSION}

It is inferred from the present study that the tropical tree species exhibit well pronounced fruiting seasonality and in the tropical dry forest landscapes, bulbuls are major frugivores and seed dispersers. Although Streblus asper belongs to fig (Ficus spp) family it has limitations in terms of attracting wide variety of fruit eating birds.

\section{Acknowledgement}

We are grateful to Dr. P.A. Azeez, Director, Salim Ali Centre for Ornithology and Natural History for the encouragement. We would like to thank Forest Department of Tamilnadu for providing necessary permission to carry out the field work.

\section{References}

[1] S. Ali, Journal of Bombay Natural History Society 35 (1931) 144-149.

[2] R. Aruna. P. Balasubramanian, P. Radhakrishnan, The Indian Forester 135(10) (2009) 1308-1316.

[3] P. Balasubramanian, Journal of Bombay Natural History Society 93(3) (1996) 428-441.

[4] P. Balasubramanian, S. N. Prasad, K. Kandavel, Role of birds in seed dispersal and natural regeneration of forest plants in Tamil Nadu. Salim Ali Centre for Ornithology and Natural History, Technical Report No.7. Coimbatore, India (1998) +43 pp.

[5] B. Beehler, Auk 100 (1983) 1-12. 
[6] R. L. Chazdon, Perspectives in Plant Ecology Evolution and Systematics 6 (2003) 51-71.

[7] G. W. Frankie, H. G. Baker, P. A. Opler, Journal of Ecology 62 (1974) 881- 919.

[8] J. D. Hooker, Flora of British India. Vol. 5. London: L. Reeve and Co (1886) + 489 pp.

[9] H. F Howe, J. Smallwood, Annual Reviews in Ecology and Systematics 13 (1982) 201-228.

[10] H. F. Howe, L. C. Westley Ecological relationships of plants and animals. Oxford University Press, Oxford (1988) + 271 pp.

[11] M. J. Justiniano, T. S. Fredericksen, Biotropica 32 (2000) 276-281.

[12] D. P. W. Medeiros, A. Lopes, C. S. Zickel, Flora 202 (2007) 513-520.

[13] L. P. C. Morellato, D. C. Talora, A. Takahasi, C. C. Bencke, E. C. Romera, V. B. Zipparro, Biotropica 32 (2000) 811-823.

[14] J. S. Singh, V. K. Singh, Current Science 63(11) (1992) 684-689

[15] C. Sun, B. A. Kaplin, K. A. Kristensen, V. Munyaligoga, J. Mvukiyumwami, K. K. Kajondo, T. C. Moermond, Biotropica 28 (1996) 668-681.

[16] L. Van der Piji, Principles of Dispersal in Higher Plants. Springer-Verlag, New York $(1972)+273$ pp.

[17] V. S. Vijayan, Ecological isolation of bulbuls with special reference to Pycnonotus cafer and Pycnonotus luteolus at Point Calimere, Tamil Nadu. Ph.D Thesis, University of Bombay, India (1975).

[18] D. G. Wenny, Evolutionary Ecology Research 3 (2001) 51-74.

[19] N. T. Wheelwright, C. H. Janson, American Naturalist 126 (1985) 777-799. 